\title{
Wild-Type Neural Progenitors Divide and Differentiate Normally in an Amyloid-Rich Environment
}

\author{
Michael J. Yetman ${ }^{1}$ and Joanna L. Jankowsky ${ }^{1,2}$ \\ Departments of ${ }^{1}$ Neuroscience and ${ }^{2}$ Neurology and Neurosurgery, Huffington Center on Aging, Baylor College of Medicine, Houston, Texas 77030
}

Adult neurogenesis is modulated by a balance of extrinsic signals and intrinsic responses that maintain production of new granule cells in the hippocampus. Disorders that disrupt the proliferative niche can impair this process, and alterations in adult neurogenesis have been described in human autopsy tissue and transgenic mouse models of Alzheimer's disease. Because exogenous application of aggregated $\mathrm{A} \beta$ peptide is neurotoxic in vitro and extracellular $\mathrm{A} \beta$ deposits are the main pathological feature recapitulated by mouse models, cell-extrinsic effects of $\mathrm{A} \beta$ accumulation were thought to underlie the breakdown of hippocampal neurogenesis observed in Alzheimer's models. We tested this hypothesis using a bigenic mouse in which transgenic expression of APP was restricted to mature projection neurons. These mice allowed us to examine how wild-type neural progenitor cells responded to high levels of $\mathrm{A} \beta$ released from neighboring granule neurons. We find that the proliferation, determination, and survival of hippocampal adult-born granule neurons are unaffected in the APP bigenic mice, despite abundant amyloid pathology and robust neuroinflammation. Our findings suggest that A $\beta$ accumulation is insufficient to impair adult hippocampal neurogenesis, and that factors other than amyloid pathology may account for the neurogenic deficits observed in transgenic models with more widespread APP expression.

\section{Introduction}

Continued production of granule neurons in the mammalian hippocampus requires a complex balance between environmental cues and cellular responses (Pathania et al., 2010). Aging and age-related diseases shift this balance ( $\mathrm{Mu}$ and Gage, 2011; Villeda et al., 2011), and Alzheimer's disease (AD) in particular has a direct impact on the hippocampal cellular and chemical milieu. Neurodegeneration early in AD damages the main excitatory input from entorhinal cortex to the dentate gyrus (GómezIsla et al., 1996), whereas pathological aggregation of amyloid- $\beta$ into extracellular plaques induces a robust immune response and compromises vascular function. Together, these pathologies could converge to substantially curtail neuronal production.

Given the extent of hippocampal damage in $\mathrm{AD}$, surprisingly few studies have examined adult neurogenesis in autopsyconfirmed tissue (Jin et al., 2004; Boekhoorn et al., 2006; Perry et al., 2012). Considerably more work has been done in mouse models of $\mathrm{AD}$, where most studies report diminished neurogenesis (Mu and Gage, 2011). Mouse models examined to date have tested multiple familial mutations in both APP and presenilin 1 (PS1), under the control of promoters that would be active in

\footnotetext{
Received May 7, 2013; revised Sept. 20, 2013; accepted Sept. 27, 2013.

Author contributions: M.J.Y. and J.L.J. designed research; M.J.Y. performed research; M.J.Y. analyzed data; M.J.Y. and J.L.J. wrote the paper.

We thank Bryan Song and Yuanyuan Zhang for animal care, Mark Mayford for sharing the tet0-H2B-GFP line, and Andy Groves and Stacy Decker for comments on the manuscript. This work was supported by National Institutes of Health New Innovator Award DP2 0D001734. M.J.Y. was supported by National Institute on Aging Training Grant T32 AG000183.

The authors declare no competing financial interests.

Correspondence should be addressed to Dr. Joanna L. Jankowsky, Baylor College of Medicine, BCM295, One Baylor Plaza, Houston, TX 77030. E-mail: jankowsk@bcm.edu.

DOI:10.1523/JNEUROSCI.1917-13.2013

Copyright $\odot 2013$ the authors $\quad 0270-6474 / 13 / 3317335-07 \$ 15.00 / 0$
}

newborn neurons as well as their mature neuronal and nonneuronal neighbors. Neurogenesis deficits in these models could therefore be the result of cell-intrinsic effects of the transgene within the dividing progenitors, cell-extrinsic effects of transgene expression by mature cells in the surrounding niche, or a combination of both. To distinguish between these possibilities, we used a transgenic model in which APP overexpression was limited to mature neurons (Jankowsky et al., 2005). The restricted expression of transgenic APP in these mice allowed us to establish a pathological amyloid environment without genetically altering the neural progenitors themselves. Our results demonstrate that cell-extrinsic exposure to $A \beta$ and amyloid is not in and of itself harmful to adult neurogenesis.

\section{Materials and Methods}

Mice. All studies were approved by the Baylor College of Medicine Institutional Animal Care and Use Committee.

CaMKII $\alpha$-tetracycline transactivator $(T T A) \times$ tetO-APP $P_{\text {swe/ind. }}$ Tetresponsive APP transgenic line 102 (tetO-APPswe/ind 102; MMRRC stock 034845-JAX) (Jankowsky et al., 2005) and tet-activator line B CaMKII $\alpha$-TTA (Jackson ImmunoResearch Laboratories; 3010) (Mayford et al., 1996) were backcrossed to C57BL/6J for $>25$ generations before being intercrossed for these studies. Double-transgenic male offspring were mated with wild-type FVB females to produce F1 cohorts for study.

CaMKII $\alpha-T T A \times$ tetO-H2B-GFP mice. Tet-responsive mice expressing a histone 2B-GPF fusion protein (H2B-GFP) (Tumbar et al., 2004) were outcrossed from ICR onto a C57BL/6 background for several generations before mating with CaMKII $\alpha$-TTA to produce offspring for study.

Doxycycline treatment. All TTA/APP mice and control siblings were raised on doxycycline (dox; $50 \mathrm{mg}$ dox/kg chow) starting 1-3 d after birth to suppress transgene expression during postnatal development (Rodg- 
A
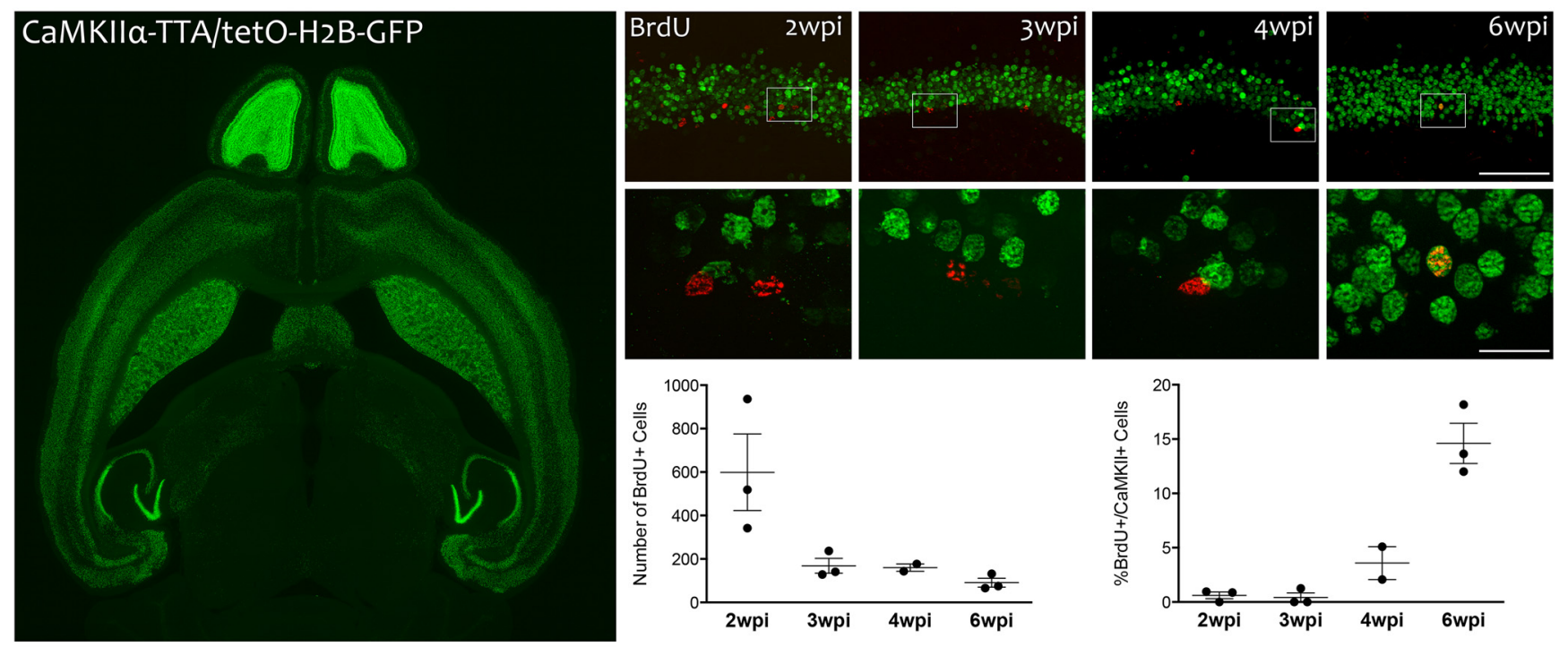

B GAD67/ tetO-GFP
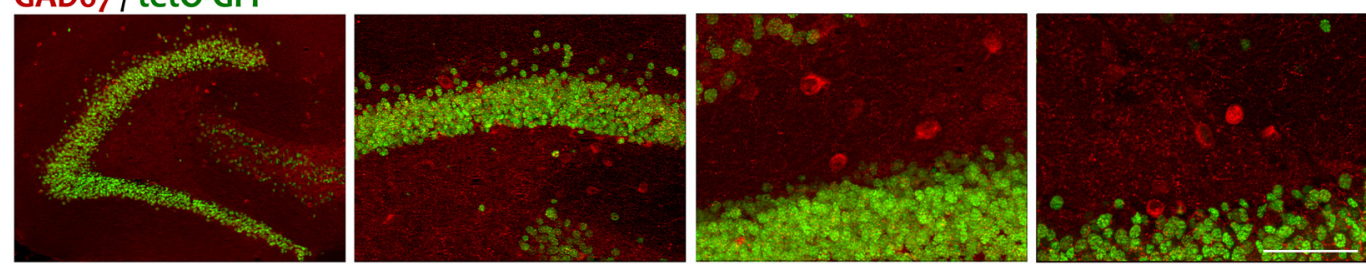

Figure 1. Expression of CaMKII $\alpha$-TTA is restricted to mature excitatory neurons in the dentate gyrus. We crossed CaMKII $\alpha$-TTA mice with a tet0-H2B-GFP reporter line to determine where and when the CaMKII $\alpha$ promoter becomes active in adult-born hippocampal neurons. A, Bigenic animals were injected with BrdU and harvested 2, 3, 4, or 6 weeks later to measure the fraction of BrdU-positive cells (red) that were colabeled with GFP (top). The total number of surviving BrdU-positive cells declined over time (left), while an increasing fraction of these cells began to express GFP (right). Scale bars: top, $100 \mu \mathrm{m}$; bottom, $33 \mu \mathrm{m}$. B, GAD67 immunostain (red) demonstrates that the CaMKIl $\alpha$ promoter is not active in hippocampal interneurons of the SGZ and hilus. Scale bars: top left, $200 \mu \mathrm{m}$; top right, $100 \mu \mathrm{m}$; bottom, $50 \mu \mathrm{m}$.

ers et al., 2012). Mice were returned to normal chow at 6 weeks of age to initiate transgene expression for the duration of the experiment.

BrdU injections. After 6 months of transgene expression, TTA/APP and control mice received either two intraperitoneal injections of BrdU spaced $6 \mathrm{~h}$ apart to assess survival $7 \mathrm{~d}$ after injection (dpi), or 6 injections spaced over $3 \mathrm{~d}$ to assess survival $30 \mathrm{dpi}$. TTA/GFP mice received two injections over one day. BrdU (B5002, Sigma) was prepared at $20 \mathrm{mg} / \mathrm{ml}$ in $0.9 \%$ saline and delivered at $150 \mathrm{mg} / \mathrm{kg}$.

Tissue harvest. TTA/APP and control littermates were perfused with PBS followed by $4 \%$ PFA in PBS. Brains were postfixed for $24 \mathrm{~h}$ at $4^{\circ} \mathrm{C}$ in $4 \%$ PFA/PBS. TTA/GFP animals were killed by $\mathrm{CO}_{2}$ inhalation and brains immersion fixed as above. Tissue was cryoprotected in 30\% sucrose before sectioning at $35 \mu \mathrm{m}$ horizontal.

Campbell-Switzer silver stain. A detailed protocol can be found at the NeuroScience Associates website as follows: http://www. neuroscienceassociates.com/Documents/Publications/campbell-switzer_ protocol.htm.

Immunohistochemistry and immunofluorescence. All stains were performed free-floating, all washes used TBS, all antibodies were diluted in blocking solution, all secondaries used at 1:500, and all steps performed at room temperature unless noted.

$\mathrm{BrdU}$. Sections were treated with $1 \% \mathrm{H}_{2} \mathrm{O}_{2}$ and $20 \%$ methanol in TBS for $30 \mathrm{~min}$ and washed several times before $2 \mathrm{~h}$ of antigen retrieval in $50 \%$ formamide $/ 300 \mathrm{~mm} \mathrm{NaCl} / 30 \mathrm{~mm}$ sodium citrate at $65^{\circ} \mathrm{C}$. After a $15 \mathrm{~min}$ wash in $300 \mathrm{~mm} \mathrm{NaCl} / 30 \mathrm{~mm}$ sodium citrate, sections were treated with $2 \mathrm{~N} \mathrm{HCl}$ for $30 \mathrm{~min}$ at $37^{\circ} \mathrm{C}$, moved to $100 \mathrm{~mm}$ borate buffer $\mathrm{pH} 8.5$ for 10 min, washed repeatedly, then blocked in 5\% normal goat serum, $1 \%$ BSA, $0.1 \%$ Triton X-100, and $0.5 \%$ Tween 20 in TBS. Sections were incubated for $48 \mathrm{~h}$ at $4^{\circ} \mathrm{C}$ in rat anti-BrdU antibody (1:200, Accurate, OBT0030), followed by biotinylated goat anti-rat secondary antibody (Vector Laboratories, BA-9400) and HRP-avidin conjugate (Vector Lab- oratories) diluted 1:50 in TBS. Staining was detected with DAB (D4418, Sigma).

Ki67. Sections were treated with $0.6 \% \mathrm{H}_{2} \mathrm{O}_{2}$ in TBS containing $0.1 \%$ Triton X-100 (TBST) for $20 \mathrm{~min}$ and washed before antigen retrieval in $10 \mathrm{~mm}$ sodium citrate, $\mathrm{pH} 6.0$, for $30 \mathrm{~min}$ at $80^{\circ} \mathrm{C}$. Sections were blocked with TBST containing 5\% normal goat serum, incubated overnight at $4^{\circ} \mathrm{C}$ with rabbit anti-Ki67 antibody (1:500, Abcam, Ab16667), followed by biotinylated goat anti-rabbit secondary antibody (Vector Laboratories, BA-1000). Staining was completed as above with Vector ABC reagents and $\mathrm{DAB}$.

Doublecortin (Dcx). Sections were treated with $\mathrm{H}_{2} \mathrm{O}_{2}$ and antigen retrieval as for Ki67 before being blocked with $10 \%$ normal donkey serum in TBST. Sections were incubated for $24 \mathrm{~h}$ with goat anti-Dcx antibody (1:500, Santa Cruz Biotechnology, sc-8066), followed by biotinylated donkey anti-goat secondary antibody (Millipore Bioscience Research Reagents, AP180B) in TBST containing 5\% normal donkey serum. Staining was completed as for Ki67.

BrdU and GFP. TTA/GFP sections were processed for BrdU immunohistochemistry as above but after blocking were incubated in a mix of primary antibodies containing rat anti-BrdU (1:200, Accurate, OBT0030) and chicken anti-GFP (1:500, Abcam, ab13970) for $48 \mathrm{~h}$ at $4^{\circ} \mathrm{C}$, followed by detection with Alexa Fluor 568-conjugated goat anti-rat IgG (Invitrogen, A-11077) and Alexa Fluor 488-conjugated goat anti-chicken IgG (Invitrogen, A-11039).

GAD67, Iba1, and GFAP. TTA/GFP and TTA/APP sections were blocked with $5 \%$ normal goat serum in TBST before incubation with rabbit anti-GAD67 antibody (1:500, Millipore, AB5992), rabbit antiIbal primary antibody (1:500, Wako, \#019-19741), or rabbit anti-GFAP primary antibody (1:500, Dako, Z0334) overnight at $4^{\circ} \mathrm{C}$, followed by detection with Alexa Fluor 568 goat anti-rabbit IgG (Invitrogen, 
A
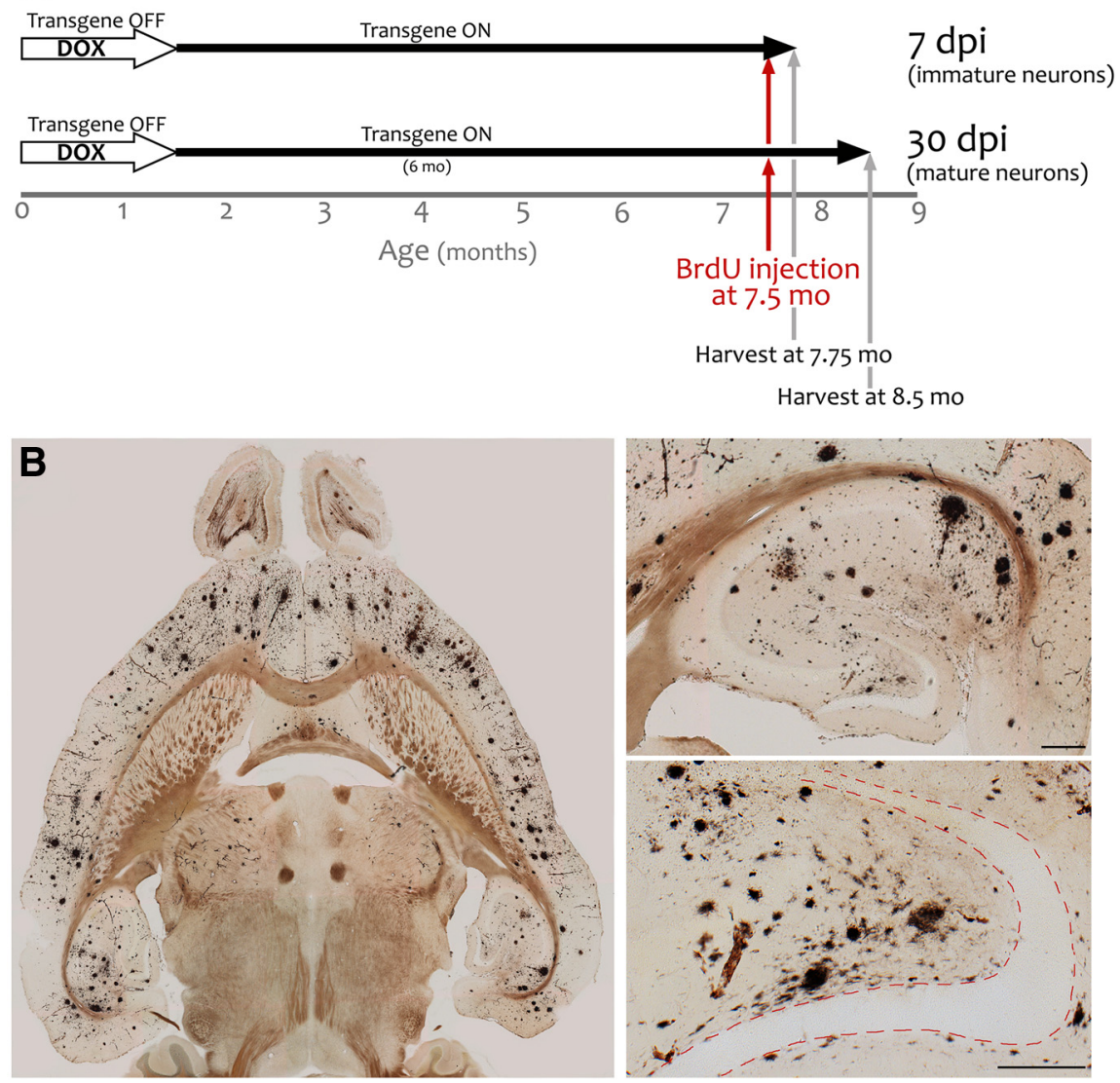

Figure 2. CaMKII $\alpha$-TTA/tet0-APP animals harbor robust amyloid pathology within the hippocampal subgranular zone at the time of BrdU injection. $A$, Transgene expression was initiated at 6 weeks of age to avoid developmental effects of APP overexpression. Six months later, mice were injected with BrdU to measure survival of adult-born neurons. $\boldsymbol{B}$, Campbell-Switzer silver stain confirmed the presence of fibrillar amyloid and diffuse plaques throughout the forebrain, including the molecular layer and hilus of the dentate gyrus. Scale bar, $200 \mu \mathrm{m}$.

A-11011, GAD67) or Alexa Fluor 488 goat anti-rabbit IgG (Invitrogen, A11008, Iba1 and GFAP).

BrdU, S100, and NeuN. TTA/APP sections were processed for BrdU immunohistochemistry as above but after blocking were incubated in a mix of primary antibodies containing rat anti-BrdU (1:200, Accurate, OBT0030), rabbit anti-S100 (1:500, Dako, Z0311), and mouse antiNeuN (1:500, Millipore, MAB377) for $24 \mathrm{~h}$ at $4^{\circ} \mathrm{C}$, followed by detection with Alexa Fluor 568-conjugated goat anti-rat IgG (Invitrogen, A-11077), Alexa Fluor 488-conjugated goat anti-mouse IgG IInvitro- $^{-}$ gen, A-21121), and Alexa Fluor 647-conjugated donkey anti-rabbit IgG (Invitrogen, A-31573). Sections were coverslipped in ProLong Gold antifade reagent (Invitrogen, P36930).

Cell quantification. Cell counts were made from 1 in 6 series of sections spanning the full dorsoventral extent of the hippocampus. DAB-stained cells (Ki67, BrdU, Dcx) located within the subgranular zone (SGZ) and inner third of the granule cell layer were counted manually by an experimenter blind to genotype using a Zeiss AxioExaminer.Z1 microscope and a Plan-Apochromat 40×/0.95 NA objective lens. Fluorescently labeled nuclei (BrdU, BrdU/GFP, BrdU/S100/NeuN) were counted from optical sections captured at $20 \times$ magnification with a Zeiss Apotome device, and confirmed by reimaging at $40 \times$. Both hemispheres were counted and averaged, and the sum multiplied by 6 to estimate positive cells per hemisphere.

Statistical analysis. All statistics were done using Prism 6.0 (GraphPad). Comparisons were done by one-way ANOVA followed by Tukey post hoc testing, except for percentage composition of $30 \mathrm{dpi}$ BrdU cells, which was analyzed by two-way ANOVA with Tukey post hoc. All graphs display group mean \pm SEM.

\section{Results}

CaMKII $\alpha$-TTA expression is restricted to mature forebrain neurons

Several groups have reported deficits in the proliferation, survival, or morphology of adult-born hippocampal neurons of APP transgenic mice ( $\mathrm{Mu}$ and Gage, 2011). However, the nonspecific expression of past models could not distinguish between the effects of transgenic APP fragments released extracellularly and mutant APP expressed within the dividing precursors themselves. To overcome this limitation, we studied a transgenic mouse in which mutant APP was restricted to mature forebrain neurons. This model uses the calcium/calmodulin-dependent protein kinase II- $\alpha$ (CaMKII $\alpha$ ) promoter to control expression of the TTA, which in turn drives expression of TTA-responsive transgenes via the tetO promoter (Mayford et al., 1996).

To verify that tet-inducible transgenes are excluded from hippocampal neural progenitor cells (NPCs) and immature neurons, we bred the CaMKII $\alpha$-TTA driver line to a tet-responsive GFP reporter line (Fig. 1) (Tumbar et al., 2004). We injected the bigenic TTA/GFP animals with BrdU and quantified the total number of BrdU-positive cells in the SGZ and inner third of the granule cell layer. By comparing the colocalization of GFP and BrdU at 2, 3, 4, and 6 weeks after injection (wpi), we were able to determine when the CaMKII $\alpha$ promoter becomes active in maturing neurons. Consistent with past studies (Ming and Song, 2011), we found that survival of adult-born NPCs decreases quickly after mitosis, from $599 \pm 176 \mathrm{BrdU}$-positive cells at 2 wpi to $91 \pm 21$ at 6 wpi (ANOVA, $p<0.05$ ). This decline in survival was inversely related to a rise in the percentage of cells coexpressing GFP. Less than $1 \%$ of BrdU-positive cells coexpressed GFP at 2-3 wpi, but this increased to $3.58 \pm 1.50 \%$ at 4 weeks and reached $14.51 \pm 1.85 \%$ by 6 weeks (ANOVA, $p<0.05$ ). These data suggest that only a negligible percentage of adult-born neurons express CaMKII $\alpha$ TTA during the 4 week window in which other groups have observed neurogenesis deficits in APP transgenic mice. The CaMKII $\alpha$-TTA driver line is therefore an appropriate tool for restricting tet-responsive transgenes to mature granule neurons while excluding expression from SGZ neural precursors and immature neurons.

In addition to excluding expression from immature neurons and non-neuronal cells, we confirmed that the CaMKII $\alpha$ promoter is absent from GABAergic interneurons in the hippocampus by immunostaining the TTA/GFP tissue for the $67 \mathrm{kDa}$ glutamate decarboxylase (GAD67). We were unable to detect GFP cells colabeled with GAD67, and conversely, found no GAD67-positive cells that expressed GFP. Thus, TTA-controlled transgenes within the hippocampus are restricted to mature glutamatergic neurons. 

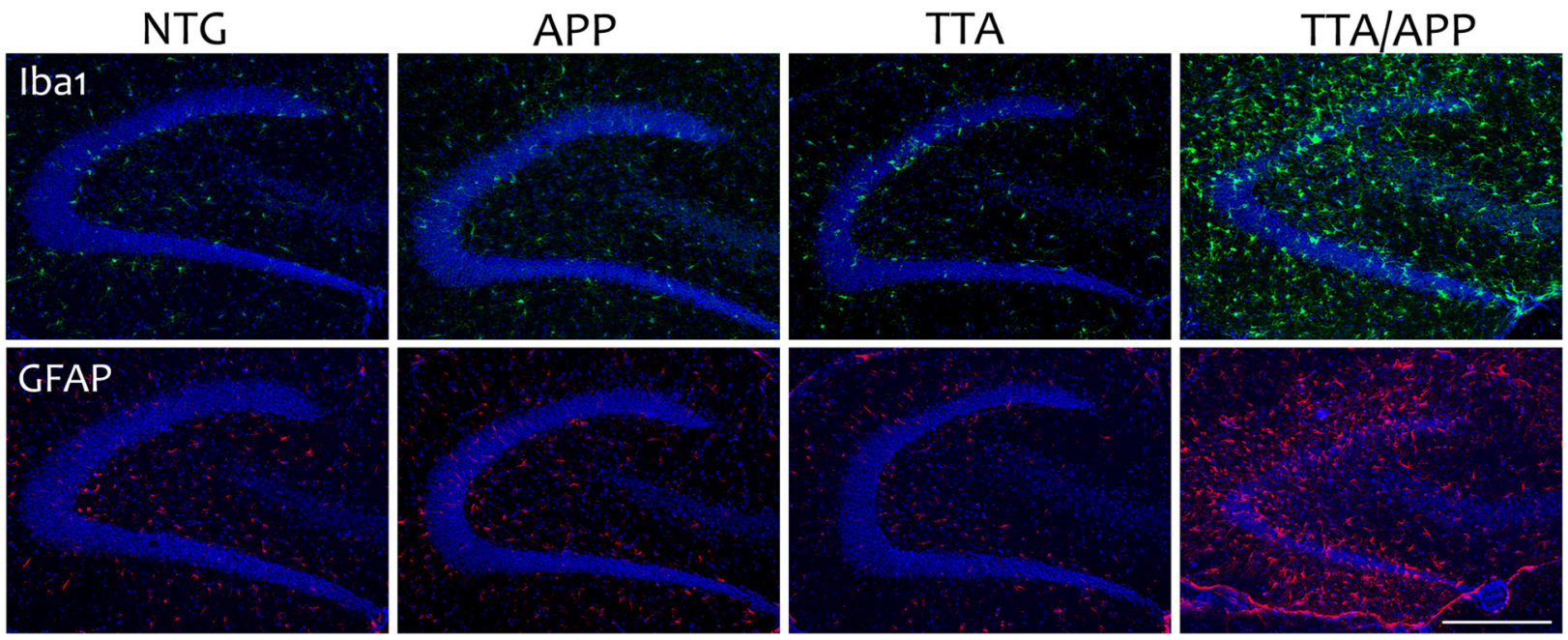

Figure 3. Amyloid induces neuroinflammation in TTA/APP mice. Immunostaining for GFAP and Iba1 reveals widespread activation of astrocytes and microglia in bigenic animals, with reactive cells found in all layers of the dentate gyrus. Scale bar, $200 \mu \mathrm{m}$.

CaMKII $\alpha$-TTA/tetO-APP bigenic animals develop amyloid pathology and inflammation in the neurogenic niche

We next bred CaMKII $\alpha$-TTA mice to a tet-responsive line encoding mouse APP with a humanized $\mathrm{A} \beta$ domain harboring the Swedish and Indiana familial mutations (tetO-APP line 102) (Jankowsky et al., 2005). After 6 months of APP overexpression, we injected TTA/APP mice and their single and nontransgenic (NTG) littermates with BrdU and harvested either 7 or 30 d later (Fig. 2). Silver staining was used to confirm that the bigenic animals had amyloid pathology throughout the forebrain, including scattered amyloid deposits across most of the dentate gyrus. This widespread pathology places NPCs within reach of $\mathrm{A} \beta$ aggregates and adjacent to granule cells with high levels of APP overexpression.

Neuroinflammation often follows amyloid deposition, and immunostaining for microglia (Iba1) and astrocytes (GFAP) was markedly increased in TTA/APP animals compared with controls (Fig. 3). Amoeboid microglia as well as hypertrophic astrocytes tended to cluster around plaques, but labeled cells could be found throughout the tissue. Morphologies of both cell types were consistent with activation and ensuing cytokine release (Patel et al., 2005). The TTA/APP model thus produces both the amyloid pathology and inflammation of other APP transgenic lines with neurogenic deficits.

\section{Proliferation, determination, and survival of adult-born hippocampal neurons are unchanged by extrinsic $\mathrm{A} \beta$ and amyloid pathology}

We next examined hippocampal neurogenesis in the TTA/APP mice by quantifying the number of adult-born cells found in the SGZ at developmental stages corresponding to proliferation, early commitment and maturation, and long-term survival. We immunostained for Ki67 to assess SGZ proliferation throughout the dorsoventral extent of the hippocampus but found no difference in number between TTA/APP animals ( $697.7 \pm 60.52$ cells) and other genotypes (NTG, $825 \pm 89.23$; APP, $823.9 \pm 53.80$; TTA, $740.3 \pm 60.67$ cells; ANOVA, $p=0.4597$; Fig. 4 ). This result suggests that proliferation of neural progenitors in the SGZ was unaffected by the surrounding pathology.

To assess later stages in adult neurogenesis, we injected TTA/ APP animals and their littermates with BrdU and harvested $7 \mathrm{~d}$ later to identify recently born neurons early in their development.
This time follows a period of precipitous cell death for adult-born hippocampal neurons (Sierra et al., 2010); and consistent with previous measures, we found that $\mathrm{BrdU}$ cell counts at $7 \mathrm{dpi}$ were $\sim 30-40 \%$ of the numbers observed by Ki67 immunostaining. More notably, we detected no difference in the number of BrdUlabeled cells 7 dpi between bigenic animals ( $243.9 \pm 42.95$ cells) and controls (NTG, $261.8 \pm 23.13$; APP, $260.6 \pm 28.62$; TTA, $279.9 \pm 30.19$ cells; ANOVA, $p=0.8916$ ).

We next performed immunostaining for Dcx to assess the survival and structure of immature neurons in the SGZ. As expected from the prolonged expression of Dcx during this stage, we identified more Dcx-positive cells than Ki67 or BrdU. Nonetheless, all four genotypes displayed comparable morphology, density, distribution, and overall numbers of Dcx-positive cells in the SGZ (NTG, $1813 \pm 88.48$; APP, $2059 \pm 200$; TTA, $1855 \pm$ 106.4; TTA/APP, $1906 \pm 202.5$ cells; ANOVA, $p=0.7120$ ).

Finally, we examined survival of adult-born cells $30 \mathrm{~d}$ after injection. Consistent with our findings for all previous markers, the number of BrdU-positive cells remaining in the dentate gyrus 30 dpi was similar across genotypes (NTG, $171.4 \pm 14.61$; APP, $178.0 \pm 18.47$; TTA, $186.0 \pm 33.38$; TTA/APP, $212.6 \pm 10.94$; ANOVA, $p=0.3945)$. We further assessed the fate of BrdUlabeled cells using markers for mature neurons (NeuN) and astrocytes (S100). Again, we found no differences between TTA/ APP animals and their control littermates in the absolute number of each cell type: $\mathrm{BrdU}^{+} / \mathrm{NeuN}^{+}$cells (NTG, $29.6 \pm 3.278$; APP, $40.0 \pm 6.0$; TTA, $45.6 \pm 6.7$; TTA/APP, $45.4 \pm 4.74$ cells; ANOVA, $p=0.0841$ ), $\mathrm{BrdU}^{+} / \mathrm{S} 100^{+}$cells (NTG, $21.0 \pm 3.3$; APP, $26.0 \pm 3.6$; TTA, $26.4 \pm 5.1$; TTA/APP, $25.7 \pm 2.3$ cells;

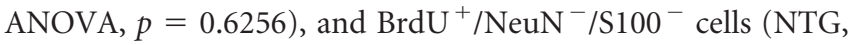
$33.0 \pm 5.0$; APP, $40.5 \pm 3.8$; TTA, $33.6 \pm 2.8$; TTA/APP, $31.71 \pm$ 3.4 cells; ANOVA, $p=0.4718$ ). Additionally, the relative fraction of each cell type as a percentage of total $\mathrm{BrdU}^{+}$cells was similar between genotypes $\left(\mathrm{NeuN}^{+}, \mathrm{S}_{100}{ }^{+}\right.$, or neither: $\mathrm{NTG}, 36.3 \pm 2.3$, $25.0 \pm 1.7,38.6 \pm 3.3$; APP, $36.7 \pm 2.9,24.3 \pm 1.5,39.0 \pm 2.4$; TTA, $42.7 \pm 1.0,24.4 \pm 1.8,32.9 \pm 2.6$; TTA/APP, $44.2 \pm 2.9$, $25.0 \pm 1.2,30.9 \pm 2.3 \%$; two-way ANOVA, $p>0.9999)$. Despite proximity to amyloid pathology, a robust inflammatory response, and neighboring granule neurons overexpressing high levels of mutant APP, we detected no change in the proliferation, development, determination, or long-term survival of adultborn hippocampal granule neurons in this model of AD. 
A
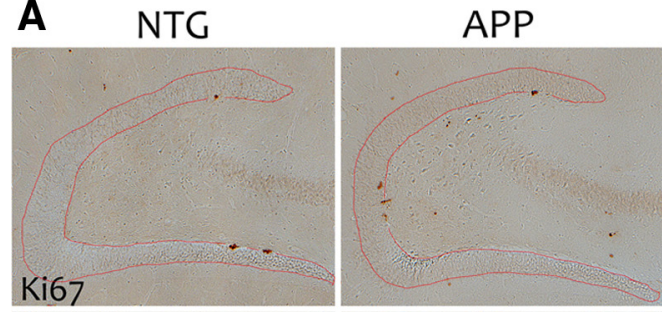

$\mathrm{BrdU}_{30} \mathrm{dpi}$

\section{B}

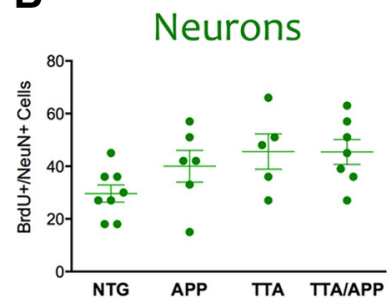

TTA
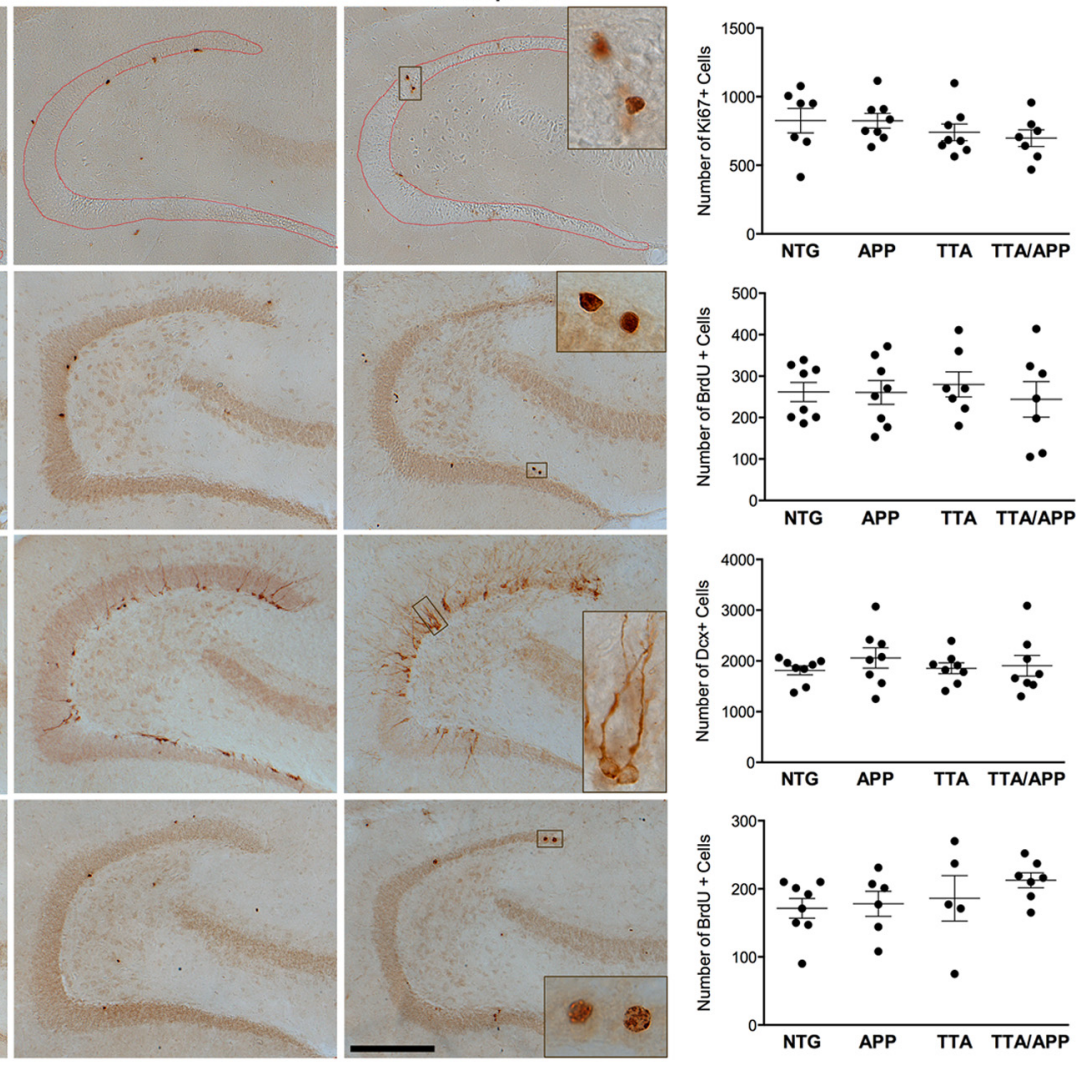

\section{Composition}
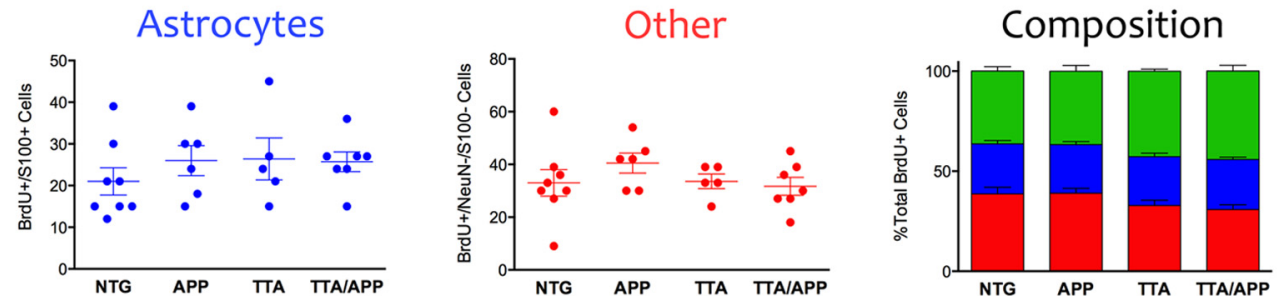

Figure 4. Neither extrinsic overexpression of APP nor amyloid pathology alters the proliferation, determination, or survival of adult-born hippocampal neurons. $\boldsymbol{A}$, We measured active proliferation using Ki67 (top row), short-term survival using BrdU $7 \mathrm{dpi}$, early maturation using Dcx, and long-term survival using BrdU 30 dpi yet found no significant differences between genotypes for any marker. One outlier in the $30 \mathrm{dpi}$ BrdU TTA/APP group was identified by Grubb's test and removed before statistical comparison. Insets, TTA/APP staining at higher magnification. Scale bar, $200 \mu \mathrm{m}$. B. We measured the fate of BrdU-labeled cells 30 dpi by costaining for NeuN and S100. We found no significant differences between TTA/APP mice and controls in either the number or the relative fraction of mature neurons, astrocytes, or other $\mathrm{BrdU}^{+}$cells.

\section{Discussion}

Past studies of isolated NPCs and transgenic APP mice have suggested that aggregated $\mathrm{A} \beta$ or sAPP acts directly on NPCs to influence the proliferation, survival, and differentiation of adultborn hippocampal neurons (Haughey et al., 2002; Caillé et al., 2004; López-Toledano and Shelanski, 2004; Heo et al., 2007). With this in mind, we set out to determine whether the reduction of adult neurogenesis observed in mouse models of AD was indeed caused by $\mathrm{A} \beta$ accumulation acting either directly on the NPCs themselves or indirectly by damaging the neurogenic niche. We limited APP overexpression to mature neurons to test whether cell-extrinsic release of $A \beta$ would be sufficient to compromise production of new granule neurons from wild-type progenitors. We examined each of the major milestones in neurogenesis from proliferation through late maturation. Unexpectedly, we found no differences in the number of cells surviving at any of these stages nor any change in their phenotypic fate between TTA/APP mice and their amyloid-free siblings.
We began the current studies expecting to find dramatic changes in hippocampal neurogenesis caused by the presence of $\mathrm{A} \beta$ and amyloid throughout the niche. We intended to use the temporal control of APP expression in these mice to examine the potential for neurogenic recovery once $A \beta$ production was suppressed. Instead, we found that features we considered fundamental to our model and shared by many others, overexpression of mutant APP releasing high levels of $A \beta$, formation of fibrillar amyloid plaques, and the subsequent inflammatory reaction, had little effect on adult hippocampal neurogenesis. How can adult neurogenesis be normal in our mice yet so impaired in other models? While the familial mutations and coexpressed transgenes vary, we suspect that the most salient difference between the TTA/APP mice and past models used to study neurogenesis results from the promoters used to drive transgene expression. The CaMKII $\alpha$ promoter used here restricts APP expression within the dentate gyrus to mature glutamatergic neurons. In contrast, promoters used in other transgenic APP models (PrP, 
Thy-1, and PDGFB) were selected for widespread expression with the goal of producing amyloid within their 2 year lifespan (Price and Sisodia, 1998). However, this advantage comes at the cost of temporal and cellular specificity, as these promoters may impart both cell-autonomous and non-cell-autonomous effects of transgenic APP to the neurogenic niche.

The most immediate difference in transgene expression between the current mice and past transgenic models is in the expression of APP within NPCs themselves. We confirmed that CaMKII $\alpha$-TTA expression is excluded from NPCs and immature neurons for at least 4 weeks after cell division. In contrast, the Prp promoter is active in adult hippocampal NPCs (Choi et al., 2008; Veeraraghavalu et al., 2010), and the innate expression of Thy-1 and PDGFB in the developing brain suggests that they, too, are likely active (Xue et al., 1991; Hutchins and Jefferson, 1992; Barlow and Huntley, 2000), where mutant APP can exert cellautonomous effects that impact neurogenesis (Cheng et al., 2011). Transgenic APP may serve as a receptor that renders NPCs more vulnerable to extracellular $\mathrm{A} \beta$ (Shaked et al., 2006), whereas release of its intracellular domain may alter transcription of neurogenic regulators Hes5, Nr2e1, and EGFR in the nucleus (Ables et al., 2010; Nakayama et al., 2011; Zheng and Koo, 2011; Beckett et al., 2012).

Alterations in the neurogenic niche by mutant APP expression in other cell types, including GABAergic neurons, astrocytes, and microglia, may also contribute to differences between the TTA/ APP mice, which lack expression in these cells, and other APP models. Under the Prp, Thy-1, and PDGFB promoters, GABAergic interneurons likely express transgenic APP (Sasahara et al., 1995; Lee et al., 2006; O’Mahony et al., 2006), whereas the Prp promoter is also expressed in astroctyes and microglia (Lesuisse et al., 2001; Choi et al., 2008). Regardless of promoter, both astrocytes and microglia react morphologically to the appearance of amyloid, and the reactive morphology is indicative of attendant inflammatory signaling that can impair neurogenesis (Carpentier and Palmer, 2009; Mandrekar-Colucci and Landreth, 2010; Li et al., 2011). The preservation of neurogenesis in the TTA/APP mice, however, suggests that the glial reaction to amyloid is not sufficient to impair the niche, even at the stage we examined. In contrast, subtle changes in GABAergic signaling observed in mice with interneuron APP expression can substantially influence the morphological and functional development of NPCs (Sun et al., 2009). Our studies cannot exclude the possibility that the structure and synaptic connections of adult-born neurons are altered in our TTA/APP mice, but by using the CaMKII $\alpha$ promoter, we have avoided transgenic modification of key cell types known to influence NPC development in the SGZ.

Our results demonstrate that the production, determination, and survival of adult hippocampal neurons can proceed unhindered in a pathological amyloid environment. $\mathrm{A} \beta$ may yet be detrimental to neurogenesis but may require additional factors, which exist to varying extents in PrP, PDGFB, or Thy-1 models to exert an effect. The timing of APP overexpression may also play a role, where onset in the embryonic brain may establish conditions that leave the remaining progenitor pool more sensitive to $\mathrm{A} \beta$ in the adult. Our findings suggest that the distinguishing features of APP transgenic models may contribute more to the previously observed changes in neurogenesis than features they share.

\section{References}

Ables JL, Decarolis NA, Johnson MA, Rivera PD, Gao Z, Cooper DC, Radtke F, Hsieh J, Eisch AJ (2010) Notch1 is required for maintenance of the reservoir of adult hippocampal stem cells. J Neurosci 30:10484-10492. CrossRef Medline

Barlow JZ, Huntley GW (2000) Developmentally regulated expression of Thy-1 in structures of the mouse sensory-motor system. J Comp Neurol 421:215-233. CrossRef Medline

Beckett C, Nalivaeva NN, Belyaev ND, Turner AJ (2012) Nuclear signalling by membrane protein intracellular domains: the AICD enigma. Cell Signal 24:402-409. CrossRef Medline

Boekhoorn K, Joels M, Lucassen PJ (2006) Increased proliferation reflects glial and vascular-associated changes, but not neurogenesis in the presenile Alzheimer hippocampus. Neurobiol Dis 24:1-14. CrossRef Medline

Caillé I, Allinquant B, Dupont E, Bouillot C, Langer A, Müller U, Prochiantz A (2004) Soluble form of amyloid precursor protein regulates proliferation of progenitors in the adult subventricular zone. Development 131: 2173-2181. CrossRef Medline

Carpentier PA, Palmer TD (2009) Immune influence on adult neural stem cell regulation and function. Neuron 64:79-92. CrossRef Medline

Cheng N, Cai H, Belluscio L (2011) In vivo olfactory model of APP-induced neurodegeneration reveals a reversible cell-autonomous function. J Neurosci 31:13699-13704. CrossRef Medline

Choi SH, Veeraraghavalu K, Lazarov O, Marler S, Ransohoff RM, Ramirez JM, Sisodia SS (2008) Non-cell-autonomous effects of presenilin 1 variants on enrichment-mediated hippocampal progenitor cell proliferation and differentiation. Neuron 59:568-580. CrossRef Medline

Gómez-Isla T, Price JL, McKeel DW Jr, Morris JC, Growdon JH, Hyman BT (1996) Profound loss of layer II entorhinal cortex neurons occurs in very mild Alzheimer's disease. J Neurosci 16:4491-4500. Medline

Haughey NJ, Liu D, Nath A, Borchard AC, Mattson MP (2002) Disruption of neurogenesis in the subventricular zone of adult mice, and in human cortical neuronal precursor cells in culture, by amyloid $\beta$ peptide: implications for the pathogenesis of Alzheimer's disease. Neuromolecular Med 1:125-135. CrossRef Medline

Heo C, Chang KA, Choi HS, Kim HS, Kim S, Liew H, Kim JA, Yu E, Ma J, Suh $\mathrm{YH}$ (2007) Effects of the monomeric, oligomeric, and fibrillar $\mathrm{A} \beta 42$ peptides on the proliferation and differentiation of adult neural stem cells from subventricular zone. J Neurochem 102:493-500. CrossRef Medline

Hutchins JB, Jefferson VE (1992) Developmental distribution of plateletderived growth factor in the mouse central nervous system. Brain Res Dev Brain Res 67:121-135. CrossRef Medline

Jankowsky JL, Slunt HH, Gonzales V, Savonenko AV, Wen JC, Jenkins NA, Copeland NG, Younkin LH, Lester HA, Younkin SG, Borchelt DR (2005) Persistent amyloidosis following suppression of $\mathrm{A} \beta$ production in a transgenic model of Alzheimer's disease PLoS Med 2:e355. CrossRef

Jin K, Peel AL, Mao XO, Xie L, Cottrell BA, Henshall DC, Greenberg DA (2004) Increased hippocampal neurogenesis in Alzheimer's disease. Proc Natl Acad Sci U S A 101:343-347. CrossRef Medline

Lee WC, Huang H, Feng G, Sanes JR, Brown EN, So PT, Nedivi E (2006) Dynamic remodeling of dendritic arbors in GABAergic interneurons of adult visual cortex. PLoS Biol 4:e29. CrossRef Medline

Lesuisse C, Xu G, Anderson J, Wong M, Jankowsky J, Holtz G, Gonzalez V, Wong PC, Price DL, Tang F, Wagner S, Borchelt DR (2001) Hyperexpression of human apolipoprotein $\mathrm{E} 4$ in astroglia and neurons does not enhance amyloid deposition in transgenic mice. Hum Mol Genet 10: 2525-2537. CrossRef Medline

Li C, Zhao R, Gao K, Wei Z, Yin MY, Lau LT, Chui D, Hoi Yu AC (2011) Astrocytes: implications for neuroinflammatory pathogenesis of Alzheimer's disease. Curr Alzheimer Res 8:67-80. CrossRef Medline

López-Toledano MA, Shelanski ML (2004) Neurogenic effect of $\beta$-amyloid peptide in the development of neural stem cells. J Neurosci 24:5439-5444. CrossRef Medline

Mandrekar-Colucci S, Landreth GE (2010) Microglia and inflammation in Alzheimer's disease. CNS Neurol Disord Drug Targets 9:156-167. CrossRef Medline

Mayford M, Bach ME, Huang YY, Wang L, Hawkins RD, Kandel ER (1996) Control of memory formation through regulated expression of a CaMKII transgene. Science 274:1678-1683. CrossRef Medline

Ming GL, Song H (2011) Adult neurogenesis in the mammalian brain: significant answers and significant questions. Neuron 70:687-702. CrossRef Medline

Mu Y, Gage FH (2011) Adult hippocampal neurogenesis and its role in Alzheimer's disease. Mol Neurodegener 6:85. CrossRef Medline

Nakayama K, Nagase H, Koh CS, Ohkawara T (2011) $\gamma$-Secretase-regulated 
mechanisms similar to notch signaling may play a role in signaling events, including APP signaling, which leads to Alzheimer's disease. Cell Mol Neurobiol 31:887-900. CrossRef Medline

O'Mahony A, Raber J, Montano M, Foehr E, Han V, Lu SM, Kwon H, LeFevour A, Chakraborty-Sett S, Greene WC (2006) NF- $\kappa B /$ Rel regulates inhibitory and excitatory neuronal function and synaptic plasticity. Mol Cell Biol 26:7283-7298. CrossRef Medline

Patel NS, Paris D, Mathura V, Quadros AN, Crawford FC, Mullan MJ (2005) Inflammatory cytokine levels correlate with amyloid load in transgenic mouse models of Alzheimer's disease. J Neuroinflammation 2:9. CrossRef Medline

Pathania M, Yan LD, Bordey A (2010) A symphony of signals conducts early and late stages of adult neurogenesis. Neuropharmacology 58:865-876. CrossRef Medline

Perry EK, Johnson M, Ekonomou A, Perry RH, Ballard C, Attems J (2012) Neurogenic abnormalities in Alzheimer's disease differ between stages of neurogenesis and are partly related to cholinergic pathology. Neurobiol Dis 47:155-162. CrossRef Medline

Price DL, Sisodia SS (1998) Mutant genes in familial Alzheimer's disease and transgenic models. Annu Rev Neurosci 21:479-505. CrossRef Medline

Rodgers SP, Born HA, Das P, Jankowsky JL (2012) Transgenic APP expression during postnatal development causes persistent locomotor hyperactivity in the adult. Mol Neurodegener 7:28. CrossRef Medline

Sasahara M, Sato H, Iihara K, Wang J, Chue CH, Takayama S, Hayase Y, Hazama F (1995) Expression of platelet-derived growth factor B-chain in the mature rat brain and pituitary gland. Brain Res Mol Brain Res 32:63-74. CrossRef Medline

Shaked GM, Kummer MP, Lu DC, Galvan V, Bredesen DE, Koo EH (2006)
Abeta induces cell death by direct interaction with its cognate extracellular domain on APP (APP 597-624). FASEB J 20:1254-1256. CrossRef Medline

Sierra A, Encinas JM, Deudero JJ, Chancey JH, Enikolopov G, OverstreetWadiche LS, Tsirka SE, Maletic-Savatic M (2010) Microglia shape adult hippocampal neurogenesis through apoptosis-coupled phagocytosis. Cell Stem Cell 7:483-495. CrossRef Medline

Sun B, Halabisky B, Zhou Y, Palop JJ, Yu G, Mucke L, Gan L (2009) Imbalance between GABAergic and glutamatergic transmission impairs adult neurogenesis in an animal model of Alzheimer's disease. Cell Stem Cell 5:624-633. CrossRef Medline

Tumbar T, Guasch G, Greco V, Blanpain C, Lowry WE, Rendl M, Fuchs E (2004) Defining the epithelial stem cell niche in skin. Science 303:359 363. CrossRef Medline

Veeraraghavalu K, Choi SH, Sisodia SS (2010) Expression of familial Alzheimer's disease-linked human presenilin 1 variants impair enrichmentinduced adult hippocampal neurogenesis. Neurodegener Dis 7:46-49. CrossRef Medline

Villeda SA, Luo J, Mosher KI, Zou B, Britschgi M, Bieri G, Stan TM, Fainberg N, Ding Z, Eggel A, Lucin KM, Czirr E, Park JS, Couillard-Després S, Aigner L, Li G, Peskind ER, Kaye JA, Quinn JF, Galasko DR, et al. (2011) The ageing systemic milieu negatively regulates neurogenesis and cognitive function. Nature 477:90-94. CrossRef Medline

Xue GP, Rivero BP, Morris RJ (1991) The surface glycoprotein Thy-1 is excluded from growing axons during development: a study of the expression of Thy-1 during axogenesis in hippocampus and hindbrain. Development 112:161-176. Medline

Zheng H, Koo EH (2011) Biology and pathophysiology of the amyloid precursor protein. Mol Neurodegener 6:27. CrossRef Medline 